\title{
Remote Paraparesis due to a Traumatic Extradural Arachnoid Cyst Developing 2 Years after Brachial Plexus Root Avulsion Injury: Case Report and Review of the Literature
}

\author{
Abolfazl Rahimizadeh ${ }^{1}$ Saeed Ehteshami ${ }^{1}$ Touraj Yazdi ${ }^{1}$ Shagayegh Rahimizadeh ${ }^{2}$ \\ ${ }^{1}$ PAMIM Research Center, Pars Hospital, Iran University of Medical \\ Science, Tehran, Iran \\ ${ }^{2}$ Saint James School of Medicine, Chicago, Illinois, United States \\ Address for correspondence Abolfazl Rahimizadeh, MD, Department \\ of Neurosurgery, Pars Spine Institute, Pars Hospital, 67 Keshwarz Blvd, \\ 141459 Tehran, Islamic Republic of Iran \\ (e-mail: A_rahimizadeh@hotmail.com).
}

J Brachial Plex Peripher Nerve Inj 2015;10:e43-e49.

\begin{abstract}
Keywords

- brachial plexus injury

- cord herniation

- magnetic resonance imaging

- root avulsion

- spinal arachnoid cyst

Traumatic extradural arachnoid cyst is a rare entity. However, late appearance of paraparesis due to formation of an extradural arachnoid cyst as a sequel of brachial plexus injury is extremely rare and the literature regarding this issue is scarce revealing only 11 cases. Herein, we report a patient with delayed progressive spastic paraparesis appearing after a multilevel brachial plexus root avulsion injury where imaging revealed formation of a large traumatic extradural arachnoid cyst at the cervicothoracic region. Furthermore, to propose that a high-energy trauma might simultaneously result in delayed formation of an extradural arachnoid cyst. However, preganglionic root avulsion injury with pseudomeningocele formation in association with extradural arachnoid cyst is not reported previously. A case of a 36-year-old man with spastic paraparesis developing 2 years after a multilevel brachial plexus root avulsion injury is presented. Root avulsion had immediately resulted in complete paralysis of the left upper limb that had not ameliorated. Imaging studies of the cervicothoracic region disclosed left-sided multilevel pseudomeningoceles and a large extradural arachnoid cyst extending from C5 to T2. After appropriate en bloc laminotomy, the cyst was excised and the causative dural tear was closed. Subsequently, three large defects of pseudomeningoceles were obliterated with artificial dural patch for the prevention of cord herniation. This was followed with laminoplasty of the corresponding levels after dural closure. The postoperative course was uneventful and paraparesis recovered steadily within 2 months. Paraparesis even years after brachial plexus injury should be regarded as a serious event that deserves extensive imaging survey for the possibility of the formation of an extradural arachnoid cyst. Careful review of the literature disclosed that the current case is the 12th case that an extradural arachnoid cyst has developed after brachial plexus injury and the first example that the pathogenic factor that might be implicated in occurrence of this rare association could be clarified with review of the MRI features. Actually, the presence of posttraumatic pseudomeningoceles in association with an arachnoid cyst in the current case is in favor of the belief that only preganglionic root injuries that are in close proximity to the spinal canal had been the cause dural tear with remote formation of extradural arachnoid cyst.
\end{abstract}

received

January 10, 2015 accepted after revision June 3, 2015 published online July 24, 2015
DOI http://dx.doi.org/

10.1055/s-0035-1558426. ISSN 1749-7221.
Copyright $\odot 2015$ Georg Thieme Verlag

KG Stuttgart · New York
License terms

()(1) $\Theta \circledast$ 


\section{Introduction}

Brachial plexus injury is common among the young patients and majority occur in motorcycle accidents. ${ }^{1}$ The pathology results from excessive traction of the plexus and the location of the injury can be postganglionic or preganglionic near the spinal cord in the vicinity of the vertebral foramen. ${ }^{1-3}$ Partial or total root avulsion injuries are exclusively seen in preganglionic ones where formation of a pseudomeningocele is a frequent feature. ${ }^{1-3}$ In partial injuries dorsal rootlets or anterior rootlets might be torn, and combination of preganglionic and postganglionic injuries might exist.

Delayed onset of paraparesis, from several months to years after brachial plexus injury, is very rare. Two rare conditions with different mechanisms are known to be the cause of delayed deterioration after a long silent period, herniation of the cord into the cavity of the pseudomeningocele, and formation of extradural arachnoid cyst. ${ }^{4-14}$

In the latter condition, the trauma responsible for plexus injury might result in a breach in the nearby dural covering of the spinal cord at cervicothoracic vicinity where the extrusion of the intact arachnoid into the extradural compartment will result in the formation of an extradural arachnoid cyst. ${ }^{8-14}$ However, the cyst should reach to a considerable size to become symptomatic and this usually takes from 1 year up to several years known as a silent period. It seems that only preganglionic root avulsion injuries should be in close proximity to the spinal cord and its dural covering can be the cause of dural tear.

In our practice, imaging survey of delayed paraparesis in a 36-year-old man with history of traumatic brachial plexus root avulsion injury leads to depicting a large extradural arachnoid cyst at the cervicothoracic region. With excision of the cyst and closure of the dural defect, signs of long tract dysfunction disappeared within 2 months. The scenario of late occurrence of spastic paraparesis due to the formation of an extradural arachnoid cyst is an extremely rare sequel of brachial plexus injury and only 11 cases have been reported previously where the present case is the first example that association of brachial plexus root avulsion injury with an extradural arachnoid cyst is documented in magnetic resonance imaging (MRI). With demonstration of these two pathologies in a set of MR images, the pathogenesis of this combination can be verified.

\section{Case Report}

A 36-year-old man was referred to our institution with progressive weakness of the lower extremities for 2 months. He had sustained brachial plexus injury in a motor cycle accident 2 years earlier, which had caused complete paralysis of the left upper limb immediately. Neurologic examination of the left upper extremity revealed complete paralysis of the majority of the muscles innervated by the corresponding roots that make brachial plexus, except rhomboid being partially affected and diaphragm that was intact. Furthermore, combination of anhidrosis, myosis, enophthalmos, and ptosis known as Horner syndrome was absent in this patient.
Further examination disclosed spastic paraparesis with hyperactive reflexes and up-going toes.

MRI revealed multilevel cervical pseudomeningoceles at C6, $\mathrm{C} 7$, and $\mathrm{C} 8$ with enlargement of the corresponding foramina and a large cervicothoracic cystic mass extending from C5 to $\mathrm{T} 2$, with considerable compressive effect on the spinal cord displacing it anteriorly and to the right. (-Figs. 1 and 2) The cyst content had low-signal intensity at T1-weighted images and high-signal intensity at T2-weighted images, compatible with a cerebrospinal fluid (CSF) containing arachnoid cyst. Afterward and with accomplishment of computed tomographic myelography (CTM), a block at T2 level with characteristic features of an extradural compressive mass was demonstrated (-Fig. 3).

Under general anesthesia and the patient in prone position, en bloc laminotomy from C5 to T2 was done. Immediately under the laminas, there was a cyst with a rather thin capsule. The capsule was excised till a posterolaterally located dural defect was found and closed with multiple 5-0 silk sutures. Afterward, with magnification provided by surgical microscope, the corresponding enlarged defect of each pseudomeningocele was closed with artificial dural patch with interrupted sutures to prevent the possibility of cord herniation into the pseudomeningoceles in the future. After dural closure, laminoplasty with application of mini-plates was done.

Postoperative course was uneventful, but paraparesis recovered steadily within 2 months. At 3-month follow-up, postoperative MRI demonstrated that the spinal cord was free of any compressive pathology where the pseudomeningoceles were disappeared (-Fig. 4).

He remained stable at the follow-up of 3 years.

\section{Discussion}

Brachial plexus traction injuries are common lesions affecting mainly young individuals. ${ }^{1-3}$ These lesions can be situated within the spinal canal (preganglionic) or more distally at the level of the trunk or cord (postganglionic). In preganglionic lesion, the roots at one or several levels might be partially or totally avulsed. Regardless of severity of root avulsion, it might be associated with pseudomeningocele only in 21 to $57 \%$ of the cases at one or more levels. ${ }^{1-3}$

Presence of pseudomeningocele is not indicative of total root avulsion. However, with pseudomeningocele, avulsion might be partial where only posterior rootlets, anterior rootlets, or combination of both can be seen. Even, rarely a pseudomeningocele might develop without root avulsion. This rare event has been reported in five cases by Gasparotti et al. Less frequently, concurrence of preganglionic and postganglionic injuries might be seen in a patient with pseudomeningocele.

In brachial plexus injury, a thorough neurologic examination is necessary to identify the site and degree of brachial plexus injury. The strength of the upper extremity muscles innervated by the brachial plexus must be examined and graded on a scale of 0 to 5 , on a brachial plexus chart. Superficial and deep touch sensibility tests should be 

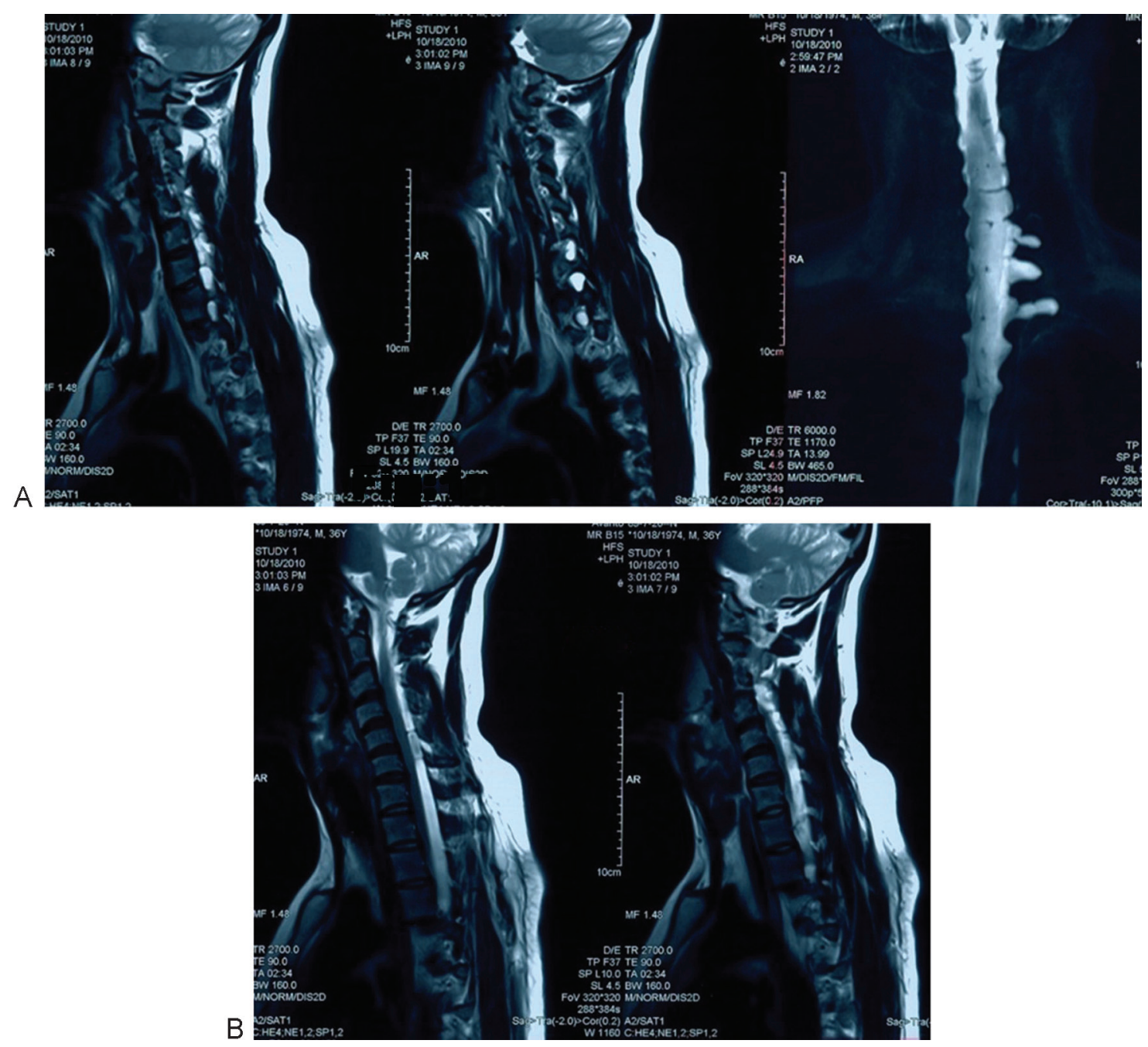

Fig. 1 (A) T1-weighted sagittal magnetic resonance (MR) images of the cervicothoracic spine and MR myelogram show pseudomeningoceles and the enlargement of corresponding foramina. (B) More medial T2-weighted sagittal MR images of the cervicothoracic region show the extradural high-intensity mass from $\mathrm{C} 5$ to $\mathrm{T} 2$

performed for each dermatome. Pain, temperature, two-point discrimination, and vibration sense evaluation are advised.

From several months to a few years after brachial plexus injury, the neurologic status of the patient may be complicat- ed with delayed neurologic dysfunction, in particular with progressive paraparesis. One of the rare causes of this event is formation of an extradural arachnoid cyst where only 11 cases have been reported previously. The details of these 11
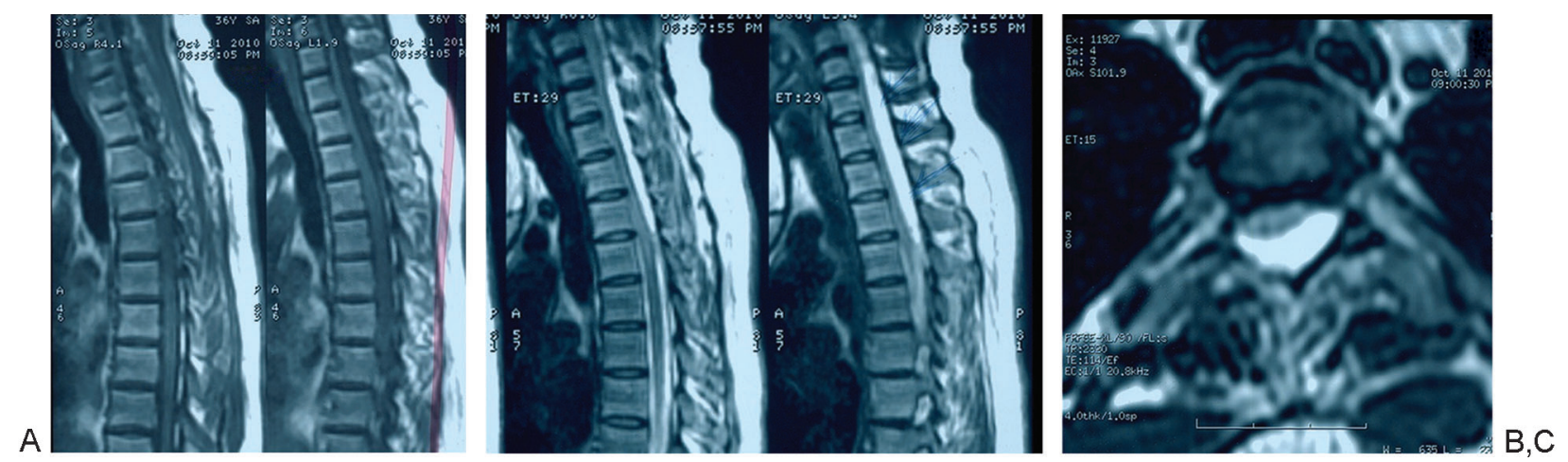

Fig. 2 (A) T1-weighted sagittal magnetic resonance (MR) images of thoracic spine show a low-intensity mass at cervicothoracic region. (B) T2weighted sagittal MR images of thoracic spine show a hyperintense mass at cervicothoracic region. (C) T2-weighted axial MR image of upper thoracic region shows an extradural hyperintense cystic mass. 

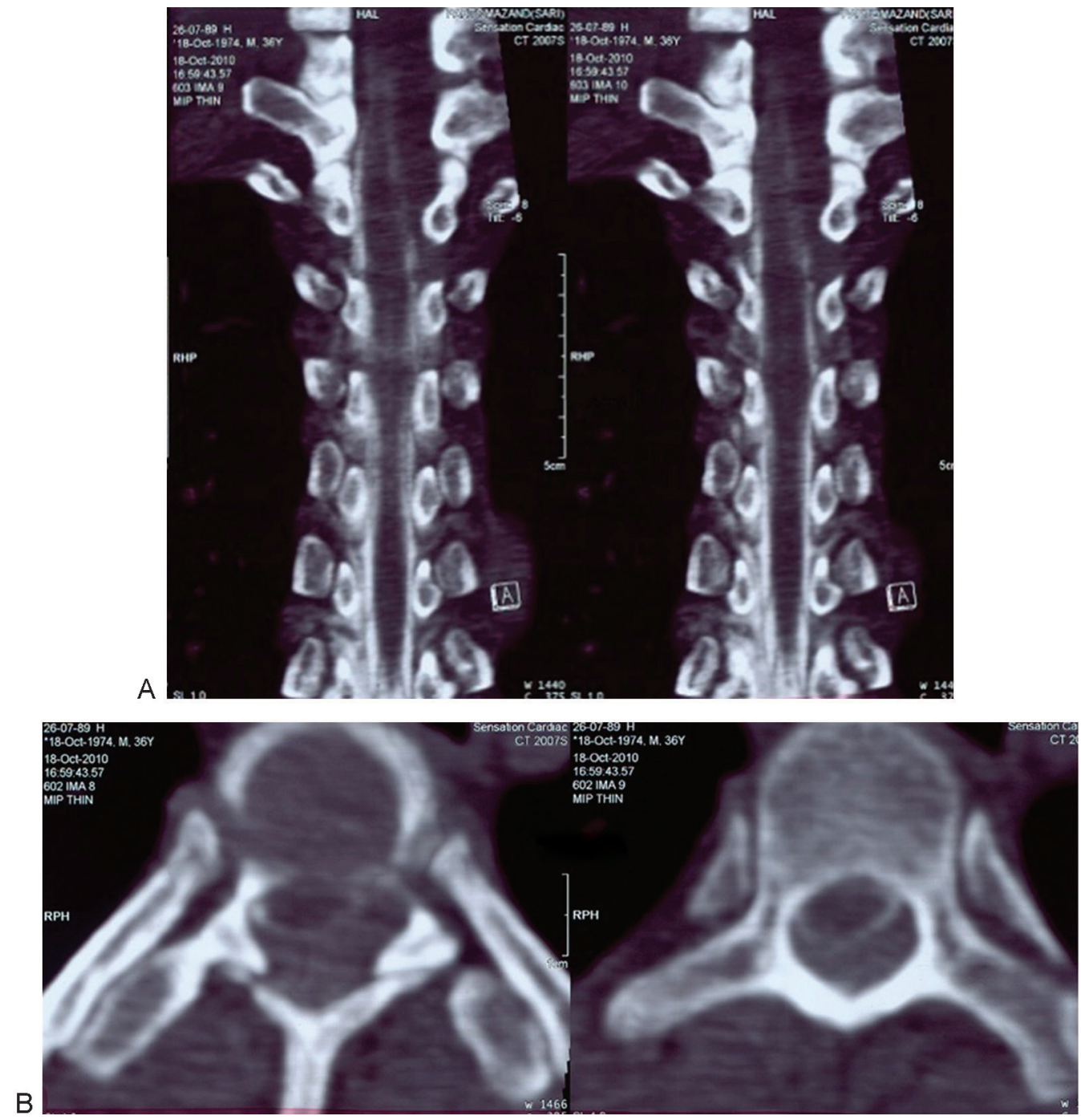

Fig. 3 (A) Reconstructed coronal computed tomographic myelogram (CTM) shows an extradural mass compressing the cord with block at second thoracic vertebra. (B) Axial CTM of the upper thoracic region depicts the extradural nature of the pathology.

cases are presented in -Table 1. However, the current case seems to be the most informative because both of the events including multilevel cervical pseudomeningoceles indicating preganglionic brachial plexus root avulsion injury and the extradural arachnoid cyst which are necessary for understanding of this rare scenario can be demonstrated in one set of MR images. ${ }^{8-14}$

By far, the spinal arachnoid cysts are benign cysts that are composed of normal or slightly thickened arachnoid capsule filled with CSF. ${ }^{11,13}$ Spinal arachnoid cysts are usually discovered intradurally and are infrequently found extradurally, whereas an intramedullary arachnoid cyst remains an exception. ${ }^{15-17}$ In extradural ones, prerequisite for the formation of the cyst is a dural defect that might be congenital or due to trauma. ${ }^{4-15}$ In traumatic extradural arachnoid cysts, trauma is the cause of dural breach that allows outpouching of the arachnoid layer and its entrance into the extradural compartment. ${ }^{8-15}$ With its gradual expansion via ball valve mechanism, the pouch becomes larger and ultimately shapes into an extradural arachnoid cyst. The scenario of the arachnoid cyst formation and its subsequent enlargement is timely, becoming symptomatic only after a rather long period of clinical stability. $^{8-15}$

A trauma of sufficient intensity imposed to the angle between the neck and shoulder, dating to the time of the accident or during breach vaginal delivery, appears to be the most likely cause of both root avulsion and dura tear responsible for delayed development of the extradural spinal arachnoid cyst. ${ }^{3}$

Imaging studies play an essential role in differentiating preganglionic injuries from postganglionic lesions, a differentiation that is crucial for determining the management of brachial plexus injuries. For decades CTM remained gold standard and was preferred as the most reliable imaging modality for the detection of avulsion injuries.

However, gradually, attempts have been made to use conventional MRI as a noninvasive tool for the investigation of preganglionic injuries. Through these attempts, MRI features of root avulsion were classified into direct and indirect ones. Tear in the rootlets or meningeal linings and signal 

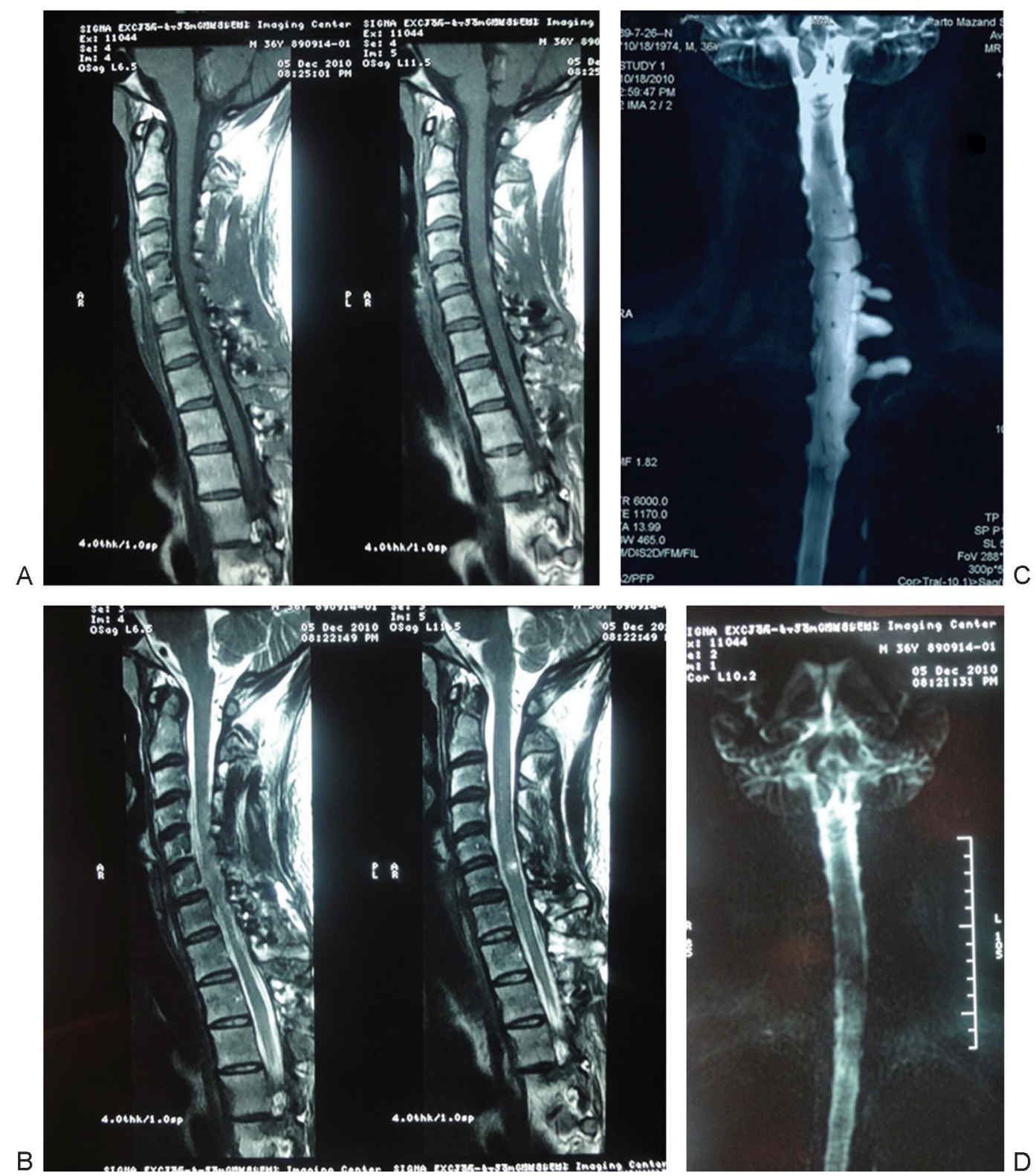

Fig. 4 (A) Postoperative T1-weighted sagittal MR images show decompressed cord. (B) Postoperative sagittal T2-weighted magnetic resonance (MR) images of cervicothoracic region show a decompressed spinal cord, the small artifacts are due to mini plates. (C) The result of the surgery is more demonstrative in comparing pre- and postoperative MR myelogram.

changes on the surface of the spinal cord at the site of the insertion of the nerve rootlets are direct where changes in muscles innervated by corresponding avulsed roots are indirect features.

For better determination of the rootlets, the volume should be placed on the axial "scout view," to include the spinal cord and a proximal part of the foramina. With this view, both torn rootlets and signal intensity of the spinal cord at the point of the insertion can be visualized. In good-quality MR images, the sensory rootlets, motor roots, and dorsal ganglion can be clearly demonstrated in a single coronal-oblique section.

In normal patients the rootlets of $\mathrm{C} 5$ to $\mathrm{C} 7$ are visualized as three or four bands with a round looking ganglion whereas the rootlets of $\mathrm{C} 8$ to $\mathrm{T} 1$ are seen as two bands with a flatlooking ganglion. Whenever the number of the bands is decreased, it is in favor of tearing off or avulsion. Moreover, in acute phase, spinal edema around the emergence of the rootlets as well as displacement of the cord toward the intact side might be seen in $20 \%$ of the cases with preganglionic avulsion injuries.

Recently, magnetic resonance myelography (MRM) has replaced invasive CTM. MRM has high sensitivity and specificity if high-quality myelography sequences are taken, providing excellent contrast between CSF and the rootlets, combined with excellent spatial resolution, useful for the demonstration of preganglionic injuries. However, identification of the lesions in MRM strongly relies on a neuroradiologist's expertise.

Furthermore, magnetic resonance neurography (MRN) or diffusion-weighted (DW) neurography is a cutting-edge 
Remote Paraparesis due to a Traumatic Extradural Arachnoid Cyst Rahimizadeh et al.

Table 1 Literature review of 12 cases with delayed formation of extradural arachnoid cyst after brachial plexus injury

\begin{tabular}{|c|c|c|c|c|c|c|c|c|}
\hline Author & Year & Sex & Age & Interval & Neurology & Length & Surgery & Outcome \\
\hline Hoffman et $\mathrm{al}^{8}$ & 1970 & $M$ & 12 & $6 y$ & Paraplegia & C4-T4 & $\begin{array}{l}\text { Laminectomy cyst } \\
\text { removal Dural de- } \\
\text { fect closure }\end{array}$ & Good \\
\hline Pye and Hickey ${ }^{9}$ & 1975 & $\mathrm{M}$ & 31 & $7 y$ & Spastic paraparesis & $\mathrm{C} 7-\mathrm{T} 2$ & $\begin{array}{l}\text { Laminectomy cyst } \\
\text { removal + dural } \\
\text { defect closure }\end{array}$ & Good \\
\hline Pye and Hickery ${ }^{9}$ & 1975 & $\mathrm{M}$ & 23 & $6 \mathrm{mo}$ & Spastic paraparesis & C6-T6 & $\begin{array}{l}\text { Laminectomy cyst } \\
\text { removal } \\
\text { Dural defect closure }\end{array}$ & Good \\
\hline Cilluffo and Miller ${ }^{10}$ & 1980 & $M$ & 40 & $3 y$ & $\begin{array}{l}\text { Increased weakness } \\
\text { of ipsilateral arm }\end{array}$ & $\mathrm{C} 3-\mathrm{C5}$ & $\begin{array}{l}\text { Laminectomy cyst } \\
\text { removal } \\
\text { Dural defect closure }\end{array}$ & Good \\
\hline Sklar et al ${ }^{11}$ & 1990 & $\mathrm{M}$ & 12 & $1 \mathrm{y}$ & Paraplegia & C4-T4 & $\begin{array}{l}\text { Laminectomy cyst } \\
\text { removal } \\
\text { Dural defect closure }\end{array}$ & Good \\
\hline $\begin{array}{l}\text { Isozumi } \\
\text { (apud Hader \& Faiholm }{ }^{12} \text { ) }\end{array}$ & 1996 & $\mathrm{M}$ & 39 & $20 y$ & $\begin{array}{l}\text { Left lower extremity } \\
\text { paresis }\end{array}$ & $\mathrm{C} 6-\mathrm{T} 1$ & $\begin{array}{l}\text { Laminectomy cyst } \\
\text { removal } \\
\text { Dural defect closure }\end{array}$ & \\
\hline Hader and Fairholm ${ }^{12}$ & 2000 & $\mathrm{M}$ & 51 & $25 \mathrm{y}$ & $\begin{array}{l}\text { Weakness of con- } \\
\text { tralateral arm }\end{array}$ & $\mathrm{C} 3-\mathrm{C} 4$ & $\begin{array}{l}\text { Laminectomy cyst } \\
\text { removal } \\
\text { Dural defect closure }\end{array}$ & Good \\
\hline Hader and Fairholm ${ }^{12}$ & 2000 & $\mathrm{M}$ & 52 & $30 y$ & $\begin{array}{l}\text { Progressive weak- } \\
\text { ness of both upper } \\
\text { extremities }\end{array}$ & C2-L1 & $\begin{array}{l}\text { Cystoperitoneal } \\
\text { shunt }\end{array}$ & Good \\
\hline Hader and Fairholm ${ }^{12}$ & 2000 & $\mathrm{M}$ & 51 & $16 y$ & $\begin{array}{l}\text { Weakness of con- } \\
\text { tralateral arm+ } \\
\text { paraparesis }\end{array}$ & $\mathrm{C} 2-\mathrm{T} 10$ & $\begin{array}{l}\text { Laminectomy cyst } \\
\text { removal } \\
\text { Dural defect closure }\end{array}$ & Good \\
\hline Miravet et al ${ }^{13}$ & 2002 & $M$ & $9 \mathrm{M}$ & $9 \mathrm{mo}$ & Paraparesis & $\mathrm{C6}-\mathrm{C} 8$ & $\begin{array}{l}\text { Laminectomy cyst } \\
\text { removal } \\
\text { Dural defect closure }\end{array}$ & Good \\
\hline Muthukumar et al ${ }^{14}$ & 2012 & $\mathrm{~F}$ & $8 \mathrm{M}$ & $8 \mathrm{mo}$ & $\begin{array}{l}\text { Increased weakness } \\
\text { of ipsilateral arm+ } \\
\text { tone of lower } \\
\text { extremity }\end{array}$ & C7-T4 & $\begin{array}{l}\text { Laminectomy cyst } \\
\text { removal } \\
\text { Dural defect closure }\end{array}$ & Good \\
\hline Current case & 2014 & $M$ & 36 & $2 y$ & Spastic paraparesis & $\mathrm{C} 5-\mathrm{T} 2$ & $\begin{array}{l}\text { Laminoplasty cyst } \\
\text { removal } \\
\text { Dural defect closure }\end{array}$ & Good \\
\hline
\end{tabular}

Abbreviations: F, female; M, male.

technique for visualizing postganglionic nerve roots. DW neurography clearly depicts the postganglionic brachial plexus in healthy patients whereas it demonstrates loss of continuity in injured nerves. DW neurography sequence with fiber tracking reconstruction allows the visualization of the spinal cord, ganglia, postganglionic nerve roots, and peripheral nerves probably because these structures have lower apparent diffusion coefficient (ADC) values than those of surrounding tissues.

Feasibility of diffusion tensor tractography (DTT) for the detection of nerve root avulsions in patients with brachial plexus injuries has been proved recently. With high-resolution tractography, the spinal cord and the rootlets from $\mathrm{C} 4$ to $\mathrm{T} 1$ can be tracked until they merge to form the primary trunks of the brachial plexus. Therefore, both total or partial avulsed nerve roots can be easily recognized on tractography either as the complete absence of fibers or their decreased in number on the injured side.

This technique simplifies the identification of the lesions compared with MRM, which strongly relies on a neuroradiologist's expertise.

Furthermore, MRI has great sensitivity and specificity for CSF containing lesions. Therefore, it remains the diagnostic procedure of choice for the detection extradural spinal arachnoid cysts. ${ }^{11-13}$ This can provide sufficient information about the length and location of the cyst. Also, detection of the dural defect might be possible with cine MRI. ${ }^{15}$

The mainstay of treatment in extradural arachnoid cyst is the closure of the defect after partial or total removal of the cyst capsule to prevent reaccumulation and recurrence of the symptoms. ${ }^{11-15}$ Nonetheless, both the cyst or the dural defect can be accessed through wide laminectomy or en bloc 
laminotomy. ${ }^{8-15}$ To prevent postlaminectomy kyphosis, in particular at transitional levels such as the cervicothoracic region and in children, laminoplasty might be preferred. ${ }^{15}$

Closure of the defect of pseudomeningocele is advised once cord herniation occurs and this can be done with or without grafting. ${ }^{4-7}$ However, the question remains regarding the prophylactic closure of the pseudomeningocele for the prevention of such rare complication. ${ }^{18}$ We believe that once dural exposure is indicated, prophylactic closure of the orifice of pseudomeningoceles might be rational.

In this association like other extradural compressive pathologies, the degree of recovery should depend on the patient's neurologic status at the time of surgery. However, the review shows that the outcome, even after establishment of paraplegia, has been surprisingly good.

In summary, in the patients with history of brachial plexus injury, with delayed appearance of new neurologic dysfunction after a period of silence, attention should be paid to the formation of an extradural arachnoid cyst. MRI remains the best diagnostic tool for depicting these two rare pathologies. Appropriate laminectomy or en bloc laminotomy, removal of the cyst, and closure of the dural defect are the main steps of the surgery.

\section{References}

1 Doi K, Otsuka K, Okamoto Y, Fujii H, Hattori Y, Baliarsing AS. Cervical nerve root avulsion in brachial plexus injuries: magnetic resonance imaging classification and comparison with myelography and computerized tomography myelography. J Neurosurg 2002;96(3, Suppl):277-284

2 Sachdev VP, Huang YP, Shah CP, Malis LI. Posttraumatic pseudomeningomyelocele (enlarging fracture?) in a vertebral body. Case report J Neurosurg 1981;54(4):545-549

3 Sunderland S. Mechanisms of cervical nerve root avulsion in injuries of the neck and shoulder. J Neurosurg 1974;41(6):705-714

4 Penfield W. Late spinal paralysis after avulsion of the brachial plexus. J Bone Joint Surg Br 1949;31B(1):40-41
5 DaSilva VR, Al-Gahtany M, Midha R, Sarma D, Cooper P. Upper thoracic spinal cord herniation after traumatic nerve root avulsion. Case report and review of the literature. J Neurosurg 2003;99 (3, Suppl):306-309

6 Yokota H, Yokoyama K, Noguchi H, Uchiyama Y. Spinal cord herniation into associated pseudomeningocele after brachial plexus avulsion injury: case report. Neurosurgery 2007;60(1):E205, discussion E205

7 Tanaka M, Ikuma H, Nakanishi K, et al. Spinal cord herniation into pseudomeningocele after traumatic nerve root avulsion: case report and review of the literature. Eur Spine J 2008;17(Suppl 2): S263-S266

8 Hoffman EP, Garner JT, Johnson D, Shelden CH. Traumatic arachnoidal diverticulum associated with paraplegia. Case report. J Neurosurg 1973;38(1):81-85

9 Pye IF, Hickey MC. Traumatic arachnoid diverticula: a report of two cases causing spinal cord compression. Br J Radiol 1975;48(575): 889-893

10 Cilluffo JM, Miller RH. Posttraumatic arachnoidal diverticula. Acta Neurochir (Wien) 1980;54(1-2):77-87

11 Sklar EM, Quencer RM, Green BA. Posttraumatic spinal pseudomeningocele: MR and clinical features. AJNR Am J Neuroradiol 1990;11(6):1184

12 Hader WJ, Fairholm D. Giant intraspinal pseudomeningoceles cause delayed neurological dysfunction after brachial plexus injury: report of three cases. Neurosurgery 2000;46(5):1245-1249

13 Miravet E, Sinisterra S, Birchansky S, et al. Cervicothoracic extradural arachnoid cyst: possible association with obstetric brachial plexus palsy. J Child Neurol 2002;17(10):770-772

14 Muthukumar N, Santhanakrishnan AG, Sivakumar K. Arachnoid cyst masquerading as obstetric brachial plexus palsy. J Neurosurg Pediatr 2012;10(1):62-63

15 Rahimizadeh A, Kaghazchi M, Shariati M, Abdolkhani E, Abbasnejad E, Rahimizadeh S. Spinal extradural arachnoid cysts. Coluna/ Columna 2013;12:112-118

16 Rahimizadeh A, Sharifi G. Anterior cervical arachnoid cyst. Asian Spine J 2013;7(2):119-125

17 Rahimizadeh A, Soufiani H. Intramedullary arachnoid cyst in association with cervical spondylosis: case report. Spine J 2013; 13(10):e21-e25

18 Pascual-Gallego M, Zimman H, Gil A, López-Ibor L. Pseudomeningocele after traumatic nerve root avulsion. A novel technique to close the fistula. Interv Neuroradiol 2013;19(4):496-499 